\title{
Hydrogeological Data Collected from a Test Well in Barceloneta, Puerto Rico
}

By Carlos Conde-Costas

U.S. GEOLOGICAL SURVEY

Open-File Report 98-267

Prepared in cooperation with the

PUERTO RICO INDUSTRIAL DEVELOPMENT COMPANY and PUERTO RICO DEPARTMENT OF NATURAL AND

ENVIRONMENTAL RESOURCES

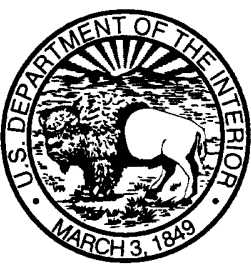




\title{
U.S. DEPARTMENT OF THE INTERIOR BRUCE BABBITT, Secretary
}

\author{
U.S. GEOLOGICAL SURVEY
}

Thomas J. Casadevall, Acting Director

The use of firm, trade, and brand names in this report is for identification purposes only and does not constitue endorsement by the U.S. Government.

For additional information write to:

District Chief

U.S. Geological Survey

GSA Center, Suite 400-15

651 Federal Drive

Guaynabo, Puerto Rico 00965-5703
Copies of this report can be purchased from:

U.S. Geological Survey

Branch of Information Services

Box 25286

Denver, CO 80225-0286 


\section{CONTENTS}

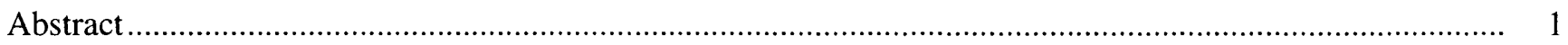

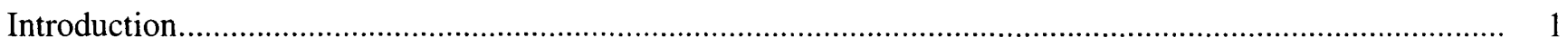

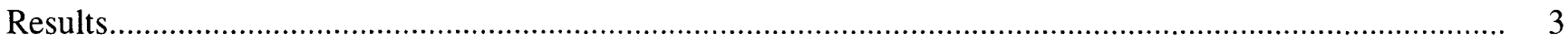

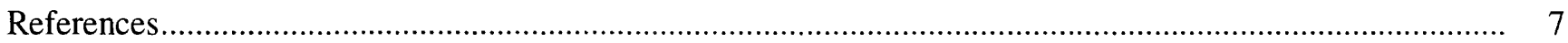

\section{ILLUSTRATIONS}

1. Map showing location of artesian wells on the north coast of Puerto Rico..................................... 2

2. Water level and specific conductance data obtained during the drilling of the test well in Barceloneta, Puerto Rico

3. Chemical classification of ground water at test well in Barceloneta, Puerto Rico

\section{TABLES}

1. General geologic units in the test well completed at Barceloneta, Puerto Rico

2. Water-quality field determinations from test well in Barceloneta, Puerto Rico

3. Concentration of selected water-quality parameters determined from test well in Barceloneta, Puerto Rico 
CONVERSION FACTORS AND ABBREVIATED UNITS

\begin{tabular}{rll}
\hline Multiply & \multicolumn{1}{c}{ By } & To obtain \\
\hline foot & 0.348 & meter \\
inch & 25.4 & millimeter \\
mile & 1.609 & kilometer \\
million gallons & 0.04381 & cubic meter \\
million gallons per day & 0.04381 & cubic meter per day \\
square mile & 259.0 & hectare \\
cubic feet per second & 448 & gallons per minute \\
\hline
\end{tabular}

Temperature: In this report temperatures are given in degrees Celsius $\left({ }^{\circ} \mathrm{C}\right)$.

Temperatures may be converted to degrees Fahrenheit $\left({ }^{\circ} \mathrm{F}\right)$ as follows:

$$
{ }^{\circ} \mathrm{F}=\left(9 / 5 \mathrm{x}{ }^{\circ} \mathrm{C}\right)+32
$$

\section{Abbreviated water-quality units used in this report:}

micrograms per liter $(\mu \mathrm{g} / \mathrm{L})$

milligrams per liter $(\mathrm{mg} / \mathrm{L})$

microsiemens per centimeter at $25^{\circ} \mathrm{C}(\mu \mathrm{S} / \mathrm{cm})$ 


\title{
Hydrogeological Data Collected from a Test Well in Barceloneta, Puerto Rico
}

\author{
By Carlos Conde-Costas
}

\begin{abstract}
A test well was drilled and installed into the north coast limestone sequence in Barceloneta, Puerto Rico, during September and November 1995. Water-quality, geologic, and hydraulic data were collected during drilling of this test well. The test well was drilled to a depth of $1,800 \mathrm{feet}$ by using a dual-wall reverse circulation rotary drill rig. The water-table surface was located at a depth of about 235 feet below land surface. The upper aquifer was identified in the Aymamón Limestone and Aguada Limestone which extend 700 feet below land surface. The lower aquifer was found in the Montebello Limestone Member of the Cibao Formation and Lares Limestone which were penetrated beginning at a depth of 868 feet to the bottom of the well at 1,800 feet below land surface. The maximum potentiometric head in the lower aquifer was 4 feet below land surface. The confining unit between the upper and lower aquifers was an impermeable calcareous claystone, found from 700 to 868 feet below land surface.
\end{abstract}

Water samples for common ions, nutrients, trace metals, synthetic organic compounds (halogenated and aromatic hydrocarbons), and physical properties (temperature, $\mathrm{pH}$, specific conductance, and alkalinity) were obtained from the upper aquifer at 440 feet below land surface and from the lower aquifer at a depth of 1,780 feet below land surface. The geochemical analyses indicate that ground water from both aquifers is predominantly a calcium-bicarbonate type.

Concentrations of common constituents, trace metals, and nutrients in the upper and lower aquifers were within the normal range for the geologic formations penetrated. Nevertheless, the sample obtained at a depth of 1,780 feet contained anomalous concentrations of lead, 20 micrograms per liter (normal < 10 micrograms per liter); molybdenum, 30 micrograms per liter (normal $<10$ micrograms per liter); total ammonia nitrogen as N, 1.5 milligrams per liter (normal $<0.2$ milligrams per liter as $\mathrm{N}$ ); and total nitrite and nitrate as N, 1.3 milligrams per liter (normal $<0.1$ milligrams per liter as $\mathrm{N}$ ). The water sample obtained from the completed well contained an anomalous concentration of dissolved mercury, 0.2 micrograms per liter (normal $<0.1$ micrograms per liter), and nitrogen species. Concentrations of synthetic organic compounds (halogenated and aromatic hydrocarbons) in the upper and lower aquifers were below the detection limits of the analytical procedures used, 0.1 micrograms per liter.

\section{INTRODUCTION}

During September and November 1995 a test well was drilled at Nycomed Puerto Rico Inc., Barceloneta, Puerto Rico (fig. 1) as part of a study of inter-aquifer water movement by the Puerto Rico Industrial Development Company, the Puerto Rico Department of Natural and Environmental Resources and the U.S. Geological Survey. The inter-aquifer study was initiated to investigate the greater than anticipated loss of hydrostatic pressure from the north coast lower (artesian) aquifer system. This report contains hydrogeologic data collected during the drilling operations of the test well drilled into the North Coast limestone sequence in Barceloneta, Puerto Rico. 


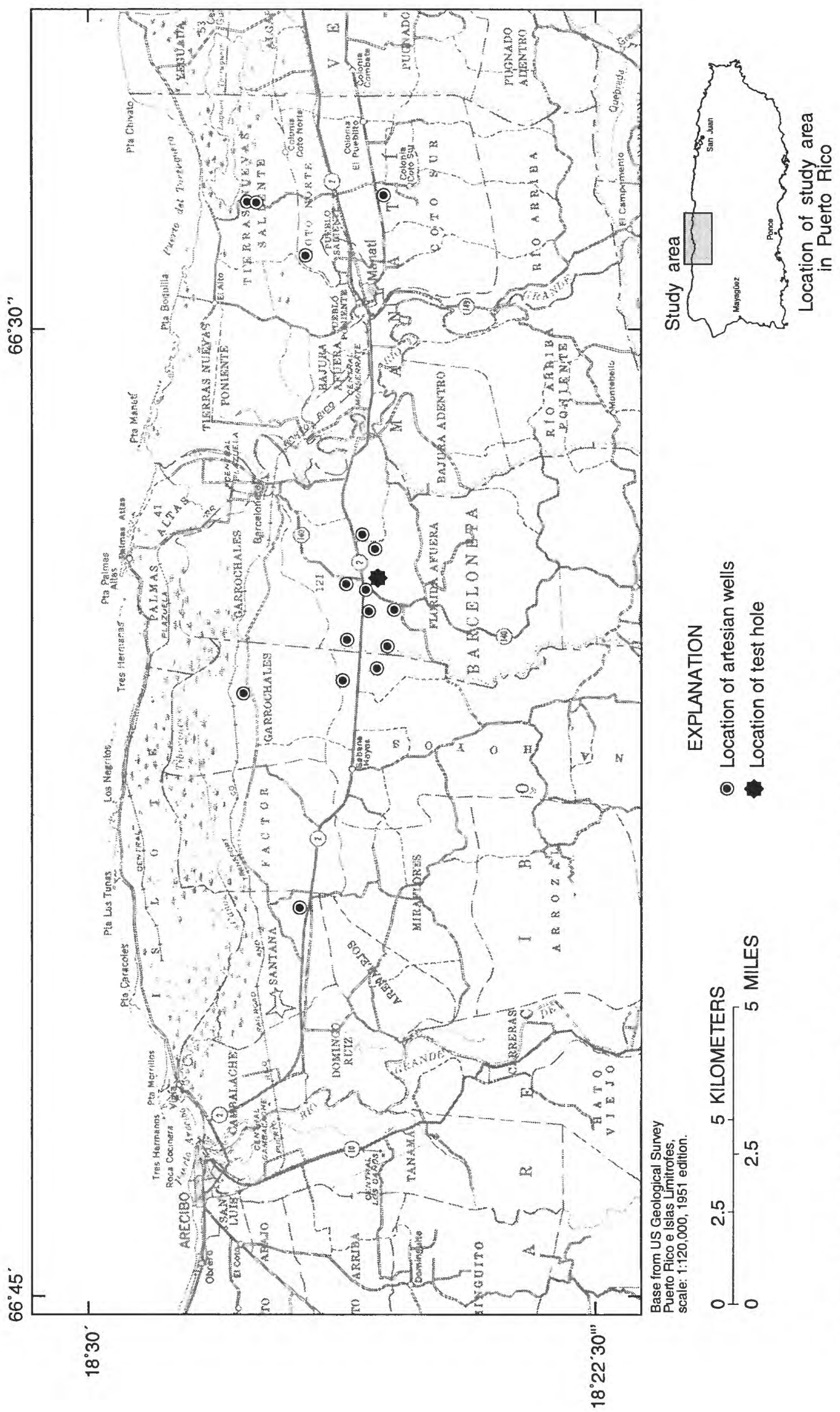

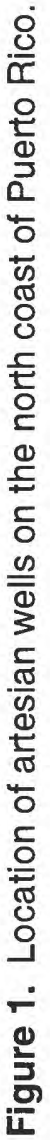


Test-well drilling was completed by using a dual-wall reverse circulation rotary drill rig. Use of this type of drill rig is often referred to as dual-wall or dual-tube drilling. This method of drilling uses flushjointed, double-walled pipe in which the drilling fluid, usually air, is injected down the annulus between the two pipes, with cuttings and ground water returned through the inner pipe. The drill pipe can be connected directly to a variety of drill bits which may include a down-hole air hammer, tricone bit, or open-center coring bit. By using the open-center coring bit on the test well, it was possible to collect continuous cores while drilling through the upper (unconfined) and lower aquifers at the site. The cores were used to improve geologic descriptions of the north coast aquifers at the drill site in terms of aquifer thickness and the location and thickness of the confining beds between the aquifers. The dual-tube method of drilling also allowed for the collection of hydraulic head and water-quality samples at depth-specific intervals.

During the course of the drilling, the cores and cuttings that were collected from the test well were stored in plastic core boxes which holds 20 feet of core or cuttings per box. Specific conductance measurements were made every 10 feet. Depth to the water surface was also determined during drilling (fig. 2). Following completion of the test well, two tests to estimate aquifer yield were conducted (at 500 and 1,800 feet below land surface datum).
Water quality samples were also collected at three distinct depths within the test well (one upper aquifer sample at 440 feet and two lower aquifer samples at 1,158 and 1,780 feet below land surface datum). Samples collected were analyzed for common ions, nutrients, trace metals, and synthetic organic compounds (halogenated and aromatic hydrocarbons). Physical characteristics (temperature, $\mathrm{pH}$, specific conductance, and alkalinity) were also measured on site. Detailed information on the procedures and methods used for on site measurements and laboratory analyses, as well as for collecting, treating, and shipping samples are given in the following U.S. Geological Survey publications "Techniques of Water Resources Investigations of the U.S. Geological Survey" Book 1, Chapter D2 and Book 5, Chapter A1.

\section{RESULTS}

The test well was drilled to a depth of 1,800 feet during September and November 1995. The test well penetrated the north coast limestone sequence (table 1). The upper aquifer was found in the Aymamón Limestone and Aguada Limestone which extend 700 feet below land surface. The water-table surface was located at a depth of about 235 feet below land surface (fig. 2). The lower aquifer is found in the Montebello Limestone Member of the Cibao Formation and Lares Limestone which were penetrated beginning at a depth of 868 feet to the end of the hole at 1,800 feet below land surface.

Table 1. General geologic units in the test well completed at Barceloneta, Puerto Rico (land surface altitude of the test well is approximately 250 feet above mean sea level)

\begin{tabular}{lrl}
\hline \multicolumn{1}{c}{ Geologic Unit } & $\begin{array}{c}\text { Depth below land } \\
\text { surface in feet }\end{array}$ \\
\hline Aymamón Limestone and Aguada Limestone & $0-700$ \\
Upper Member of the Cibao Formation & $700-868$ \\
Montebello Limestone Member of the Cibao Formation & $868-1,660$ \\
Lares Limestone & $1,660-1,800$ \\
\hline
\end{tabular}



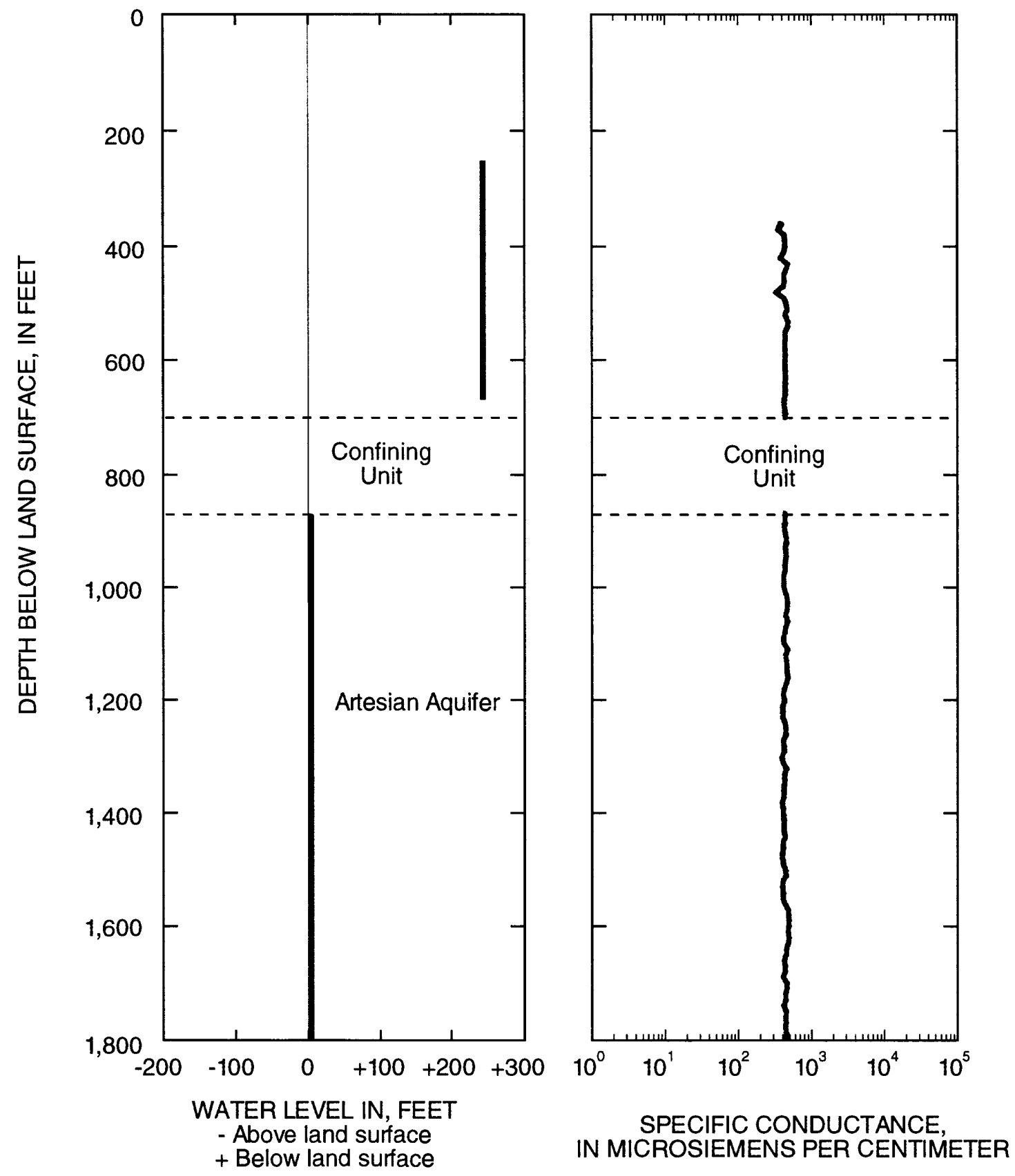

Figure 2. Water level and specific conductance data obtained during the drilling of the test well in Barceloneta, Puerto Rico. 
The maximum potentiometric head in the lower aquifer was 4 feet below land surface. The confining unit between the upper and lower aquifers is an impermeable calcareous claystone, found from 700 to 868 feet below land surface.

To obtain an estimate of relative yield in the well, two flow tests were conducted. The first test was conducted on September 14, 1995, in the upper aquifer. Discharge was measured from the 3-inch diameter inner pipe of the double walled dual-tube drill pipe. The test was conducted by raising the bottom of the drill pipe to a depth of 440 feet below land surface, leaving an open well bore interval of 60 feet, and then air-pumping the well to force discharge from the inner pipe. This measured flow was 116 gallons per minute. The second flow test was made in the lower aquifer and was conducted on September 26, 1995 , by placing the bottom of the drill pipe at a depth of 1,760 feet below land surface, leaving an open well bore interval of 40 feet. Air-pumping at this interval yielded a flow of 264 gallons per minute.

Complete water samples for common ions, nutrients, trace metals, and synthetic organic compounds (halogenated and aromatic hydrocarbons), and physical properties (temperature, $\mathrm{pH}$, specific conductance, and alkalinity) were obtained from the upper aquifer at 440 feet below land surface and from the lower aquifer at a depth of 1,780 feet below land surface during drilling on September 14 and 26, 1995. Another sample was obtained on November 29, 1995, when the well was completed (cased to 1,158 feet below land surface) and left open to the aquifer from 1,158 to 1,800 feet. Water samples were analyzed at the U.S. Geological Survey National Water Quality Laboratory in Arvada, Colorado.

Starting a depth of 360 feet below land surface, water samples for specific conductance were collected every 10 feet during drilling. The specific conductance in the upper aquifer averaged 410 microsiemens per centimeter $(\mu \mathrm{S} / \mathrm{cm})$ at 25 degrees Celsius and ranged from 320 near the water-table surface to $450 \mu \mathrm{S} / \mathrm{cm}$ (fig. 2). The specific conductance in the lower aquifer within the Montebello Limestone Member of the Cibao Formation averaged $430 \mu \mathrm{S} / \mathrm{cm}$ and ranged from 390 to $500 \mu \mathrm{S} / \mathrm{cm}$, while in the Lares Limestone specific conductance averaged $450 \mu \mathrm{S} / \mathrm{cm}$ and ranged from 410 to $470 \mu \mathrm{S} / \mathrm{cm}$. The geochemical analyses (tables 2 and 3; table 3 at end of report) of groundwater samples collected from the upper and lower aquifers indicate that ground water is predominantly a calcium-bicarbonate type in which the chemical properties of the water are dominated by alkaline earths (calcium and magnesium) and weak acids (bicarbonate) (Hem, 1989). The geochemical analyses of the first two samples are plotted in the Piper diagram in figure 3.

Table 2. Water-quality field determinations from test well in Barceloneta, Puerto Rico $\left[{ }^{\circ} \mathrm{C}\right.$, degrees Celsius; $\mu \mathrm{S} / \mathrm{cm}$, microsiemens per centimeter at 25 degrees Celsius; $\mathrm{mg} / \mathrm{L}$, milligrams per liter]

\begin{tabular}{cccccc}
\hline $\begin{array}{c}\text { Date } \\
(\mathrm{m} / \mathrm{d} / \mathrm{y})\end{array}$ & $\begin{array}{c}\text { Depth } \\
(\text { feet })\end{array}$ & $\begin{array}{c}\text { Temperature } \\
\left({ }^{\circ} \mathrm{C}\right)\end{array}$ & $\begin{array}{c}\mathrm{pH} \\
(\text { Units })\end{array}$ & $\begin{array}{c}\text { Specific } \\
\text { Conductance } \\
(\mu \mathrm{S} / \mathrm{cm})\end{array}$ & $\begin{array}{c}\text { Alkalinity } \\
(\mathrm{mg} / \mathrm{L} \text { as } \\
\left.\mathrm{CaCO}_{3}\right)\end{array}$ \\
\hline $9 / 14 / 95$ & 440 & 24.5 & 7.4 & 450 & 210 \\
$9 / 26 / 95$ & 1,780 & 23.5 & 7.6 & 475 & 243 \\
$11 / 29 / 95$ & 1,158 & 24.5 & 7.3 & 450 & 232 \\
\hline
\end{tabular}




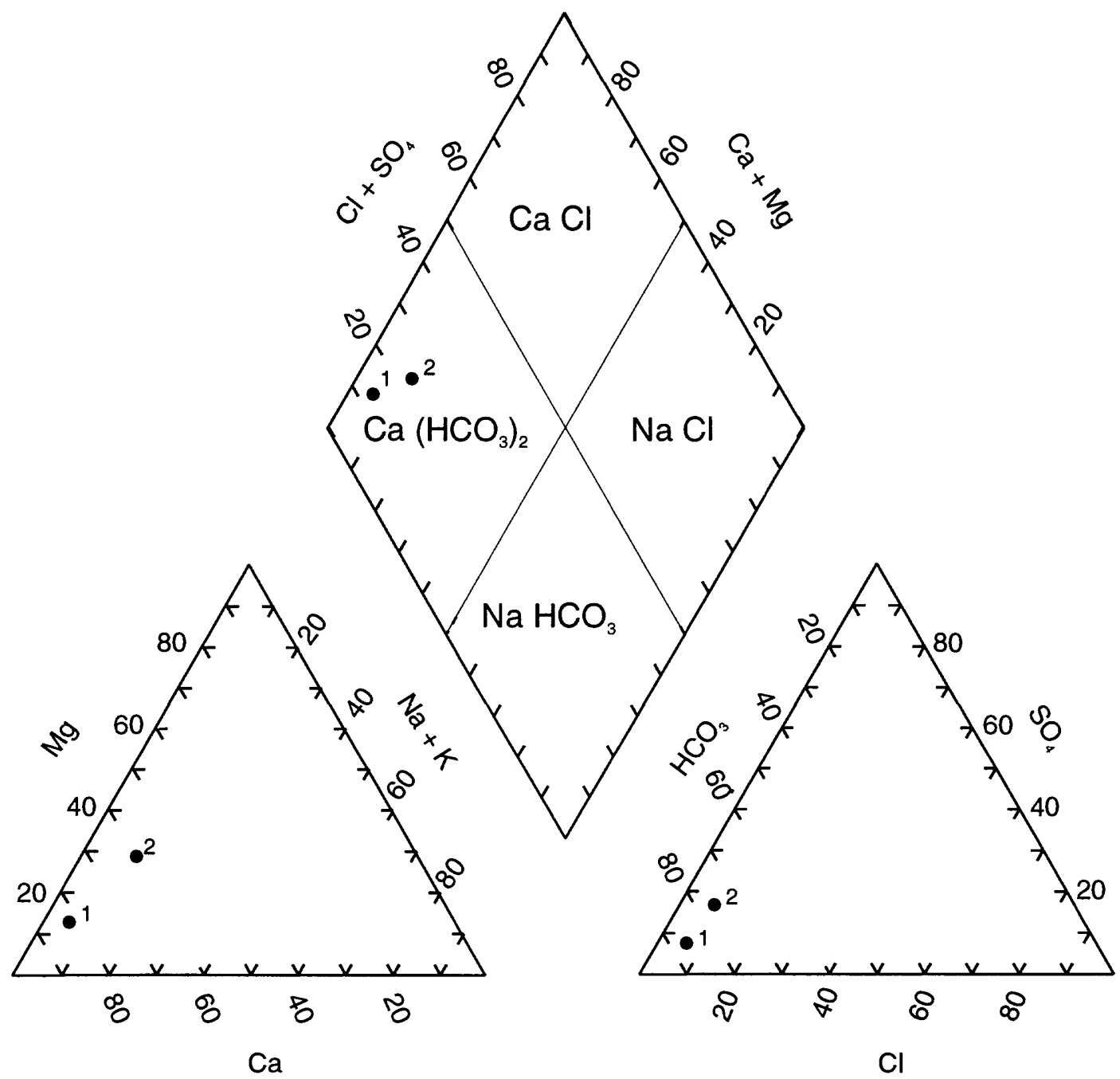

Cations

Anions

Percentage Reacting Values

$$
\begin{aligned}
& \text { EXPLANATION } \\
& -1 \text { Upper aquifer } \\
& -2 \text { Lower aquifer }
\end{aligned}
$$

Figure 3. Chemical classification of ground water at test well in Barceloneta, Puerto Rico. 
Concentrations of common constituents, trace metals, and nutrients in the upper and lower aquifers were within the normal range for the geologic formations penetrated as reported by Román-Más and Ramos-Ginés (1988) in their compilation of waterquality data for the north coast limestone aquifers. Nevertheless, the sample obtained at a depth of 1,780 feet contained anomalous concentrations of the following constituents: lead, $20 \mu \mathrm{g} / \mathrm{L}$ (normal $<10$ $\mu \mathrm{g} / \mathrm{L}$ ); molybdenum, $30 \mu \mathrm{g} / \mathrm{L}$ (normal < $10 \mu \mathrm{g} / \mathrm{L}$ ); total ammonia nitrogen as $\mathrm{N}, 1.5 \mathrm{mg} / \mathrm{L}$ (normal $<0.2$ $\mathrm{mg} / \mathrm{L}$ as $\mathrm{N}$ ); and total nitrite and nitrate as $\mathrm{N}, 1.3 \mathrm{mg} / \mathrm{L}$ (normal $<0.1 \mathrm{mg} / \mathrm{L}$ as $\mathrm{N}$ ). The water sample obtained from the completed well contained an anomalous concentration of dissolved mercury, $0.2 \mu \mathrm{g} / \mathrm{L}$ (normal $<0.1 \mu \mathrm{g} / \mathrm{L}$ ), and for nitrogen species. Concentrations of synthetic organic compounds (halogenated and aromatic hydrocarbons) in the upper and lower aquifers were below the detection limits of the analytical procedures used, $0.1 \mu \mathrm{g} / \mathrm{L}$.

\section{REFERENCES}

Hem, J.D., 1989, Study and Interpretation of the Chemical Characteristics of Natural Water: U. S. Geological Survey Water-Supply Paper 2254, 263 p.

Román-Más, Angel, and Ramos-Ginés, Orlando, 1988, Compilation of water-quality data for the north coast limestone aquifers, Puerto Rico, 1951 to 1987: U.S. Geological Survey Open-File Data Report 87-533, 133 p.

Skougstad, M.W., Fishman, M.J., Friedman, L.C., Erdmann, D.E., and Duncan, S.S., 1979, Methods for determination of inorganic substances in water and fluvial sediments: U.S. Geological Survey Techniques of Water-Resources Investigations, Book 5, Chapter A1, $626 \mathrm{p}$.

Wershaw, R.L., Fishman, M.J., and Grabbe, R.R., 1987, Methods for the determination of organic substances in water and fluvial sediments: U.S. Geological Survey Techniques of WaterResources Investigations, Book 5, Chapter A3, $90 \mathrm{p}$.

Wood, W.W., 1976, Guidelines for collection and field analyses of ground-water samples for selected unstable constituents: U.S. Geological Survey Techniques of Water-Resources Investigations, Book 1, Chapter D2, 24 p. 


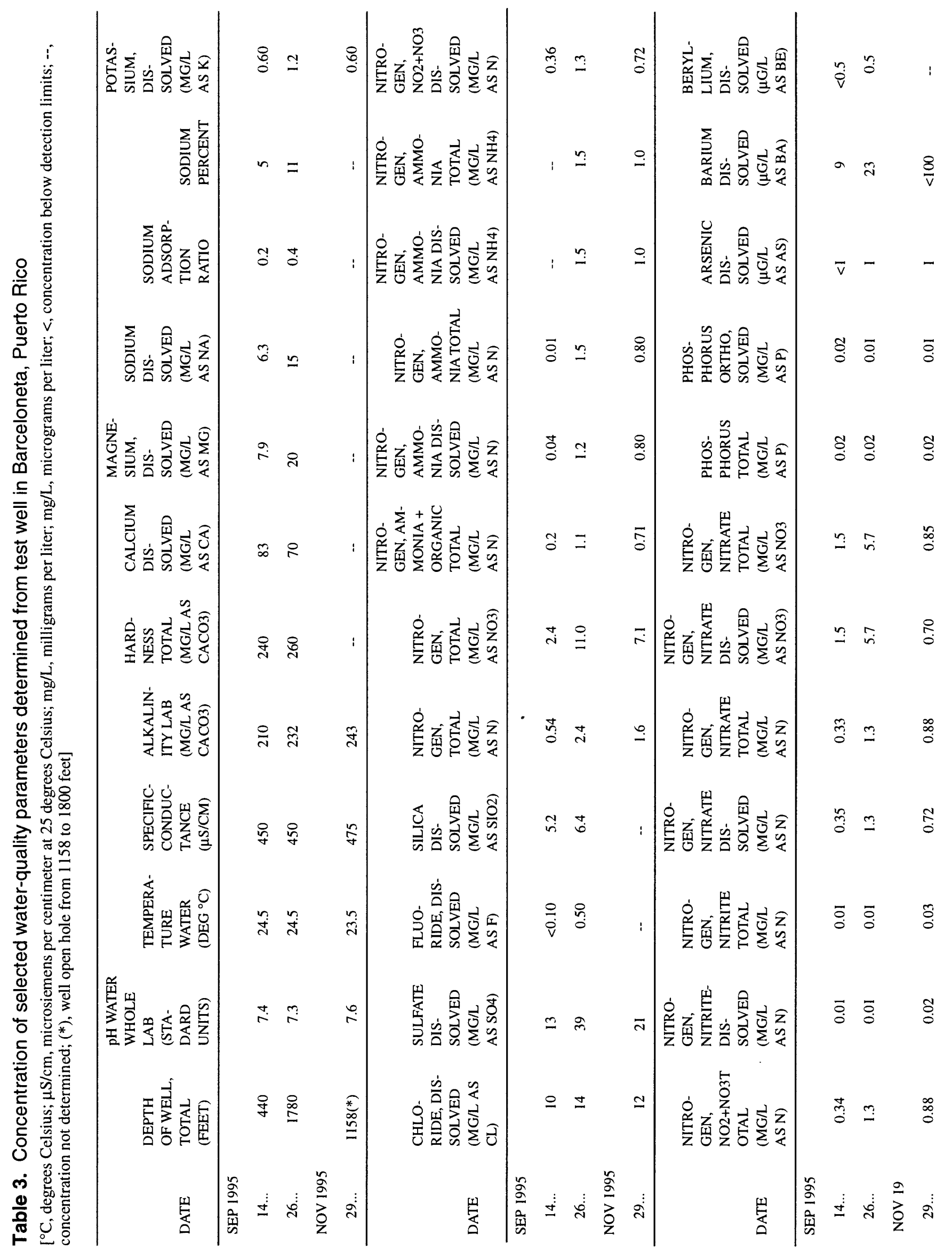




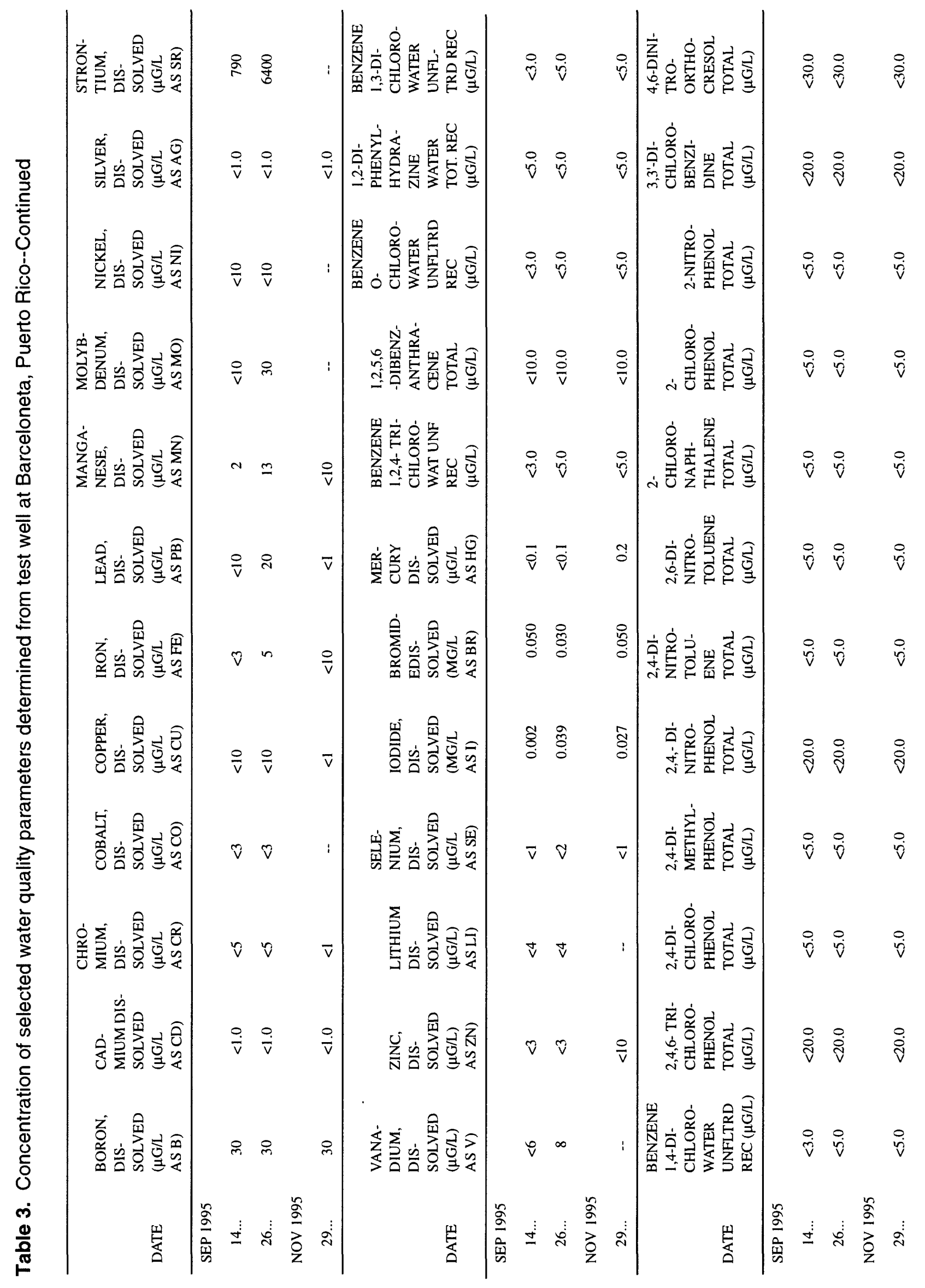




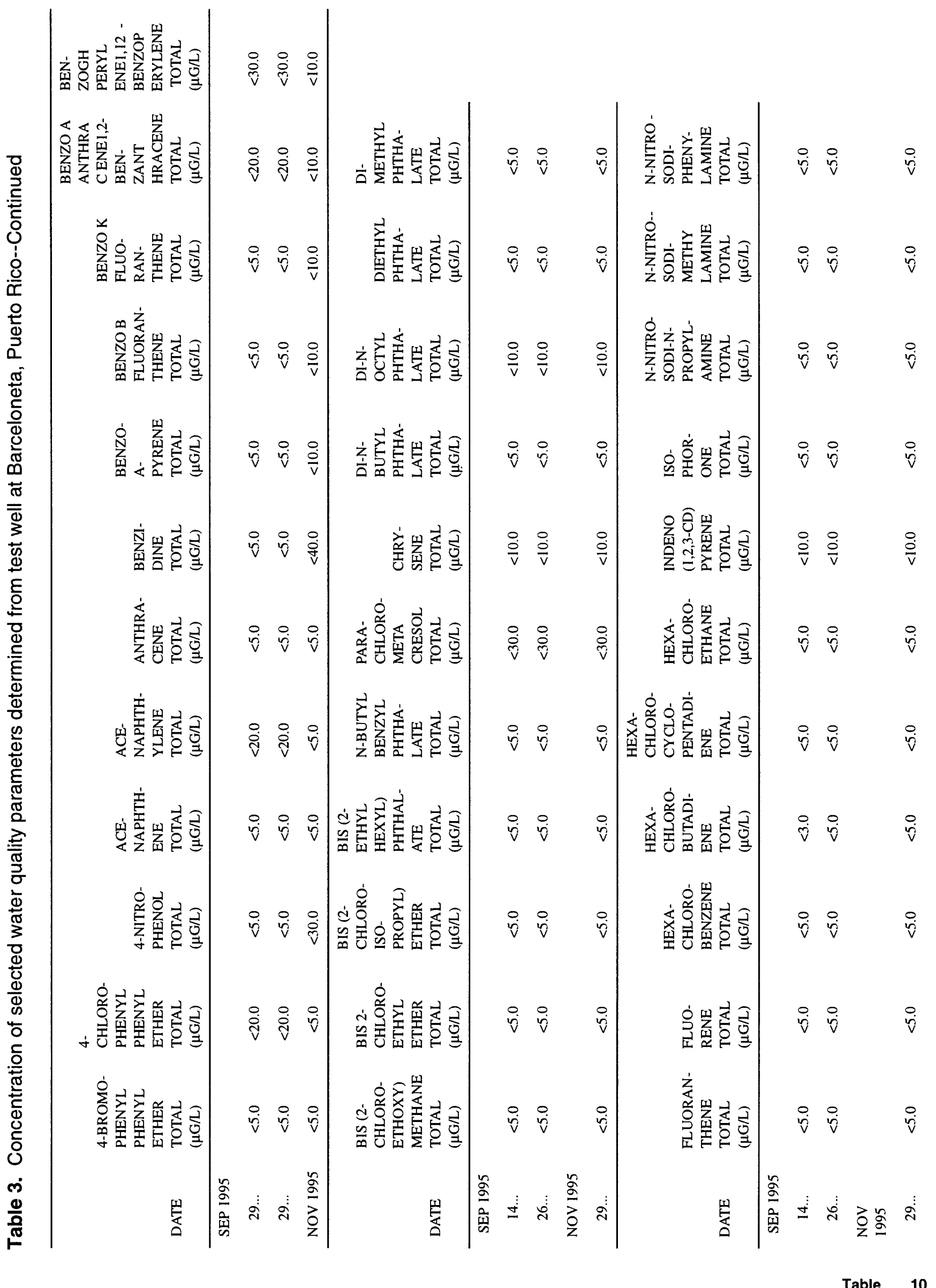




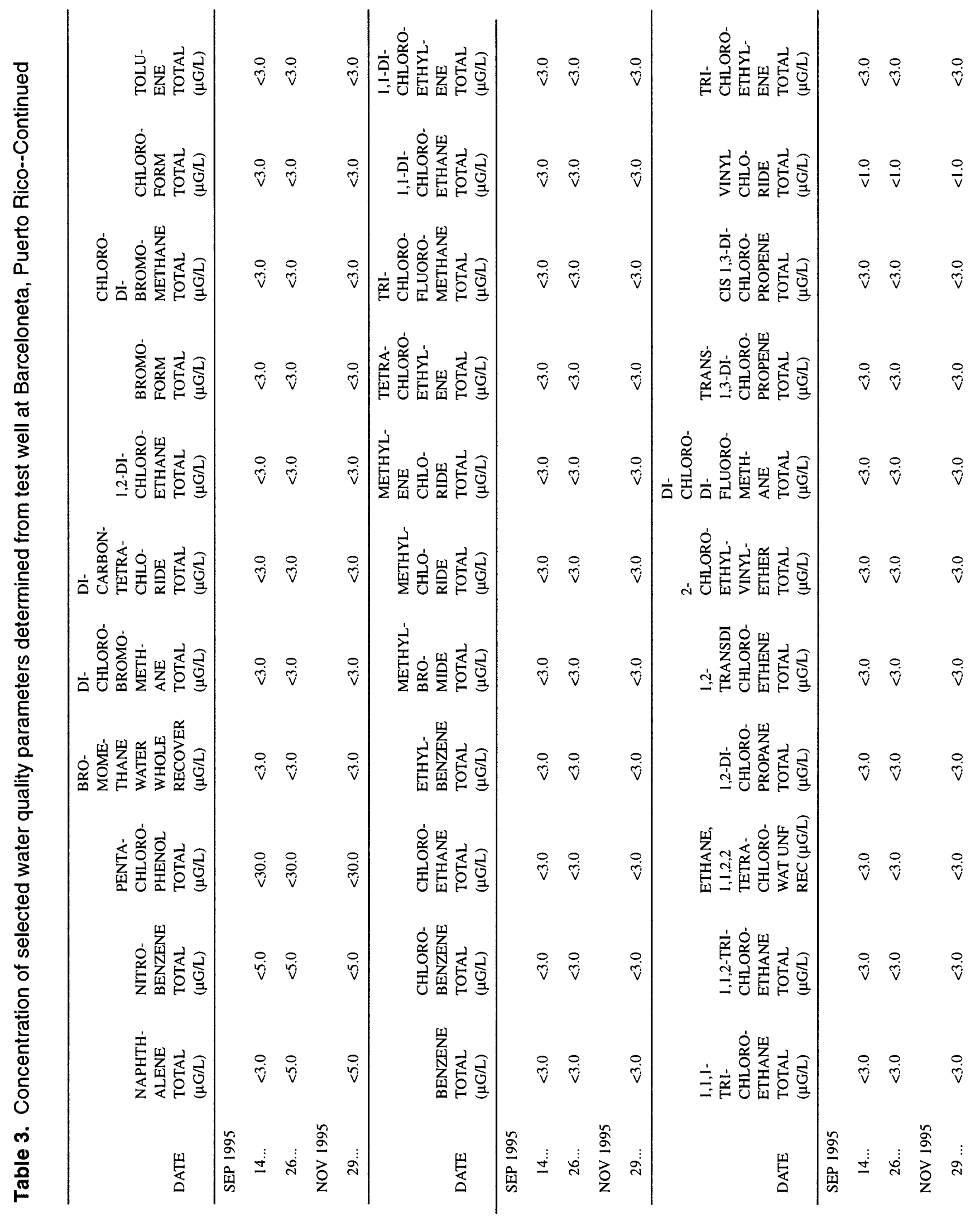




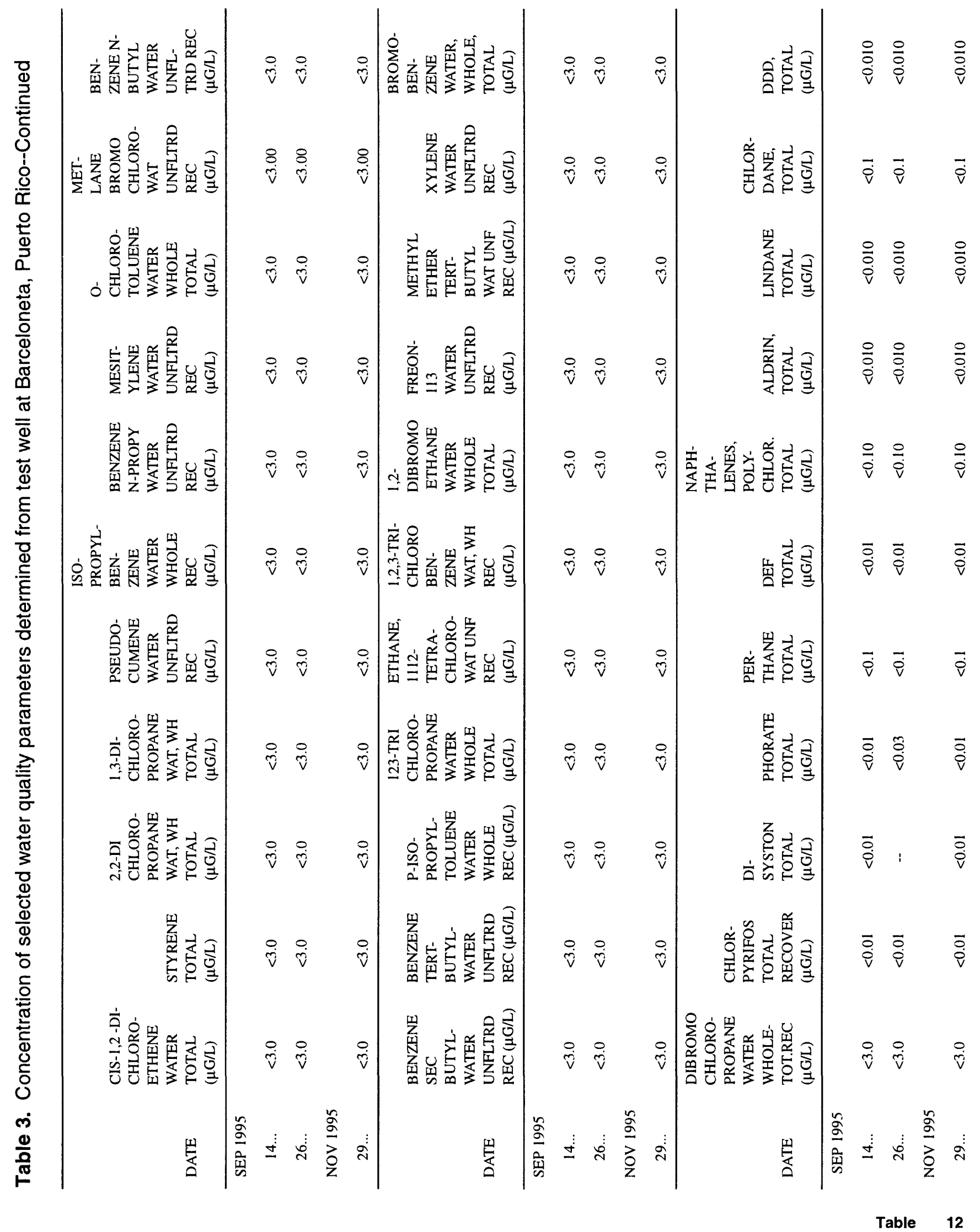




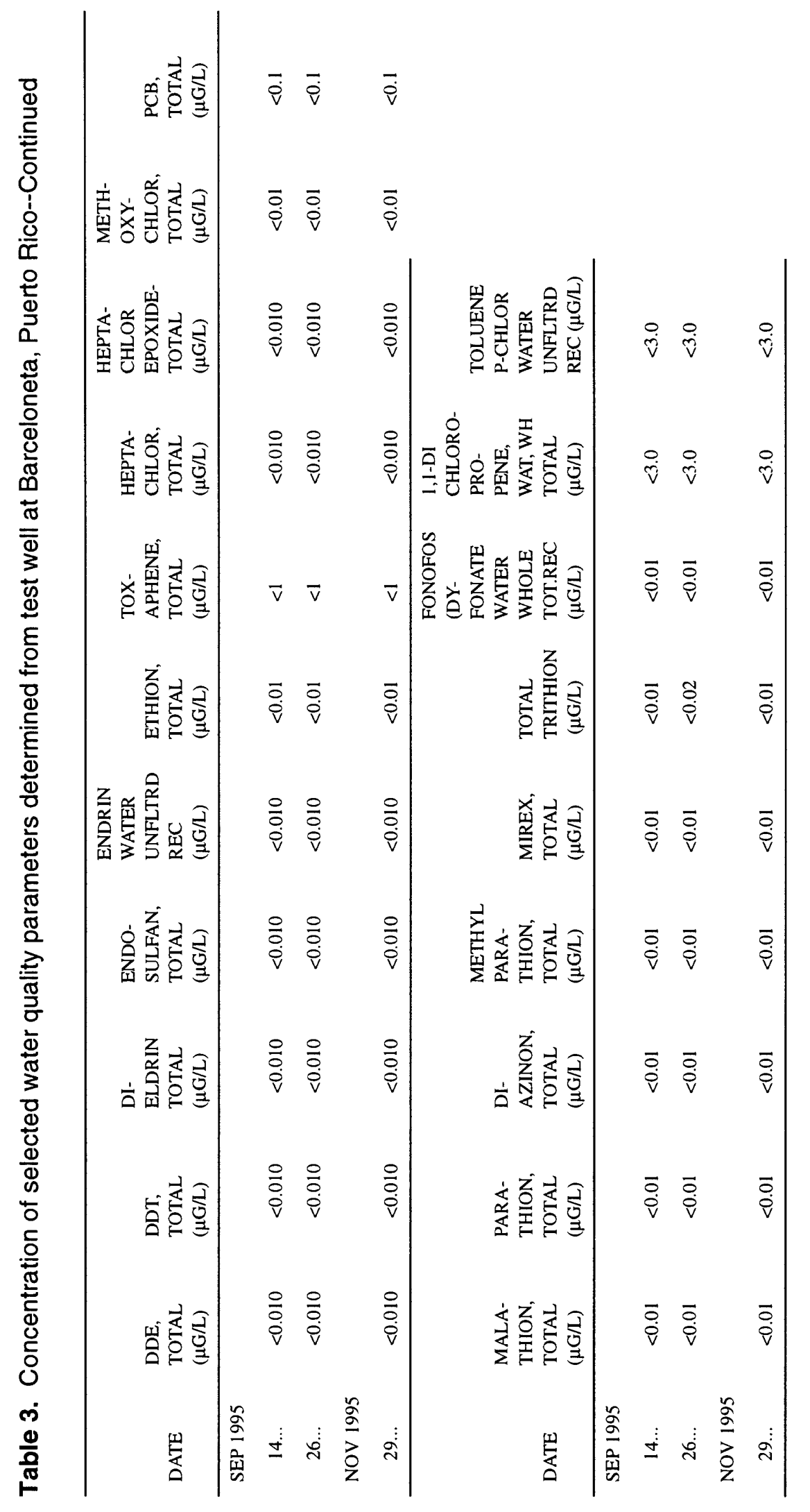

